\title{
ПРАВОСЛАВИЕ КАК СУБЪЕКТ МЕЖРЕЛИГИОЗНОГО ДИАЛОГА
}

\author{
О. И. УТКЕВИЧ
}

Витебский государственный технологический университет, г. Витебск, Беларусь

Коммуникация между представителями различных культурных традиций и религиозных исповеданий в том или ином виде существовала во все времена существования цивилизаций. Однако в современном глобализирующемся мире межкультурный и межрелигиозный диалог стал наполняться принципиально новым содержанием, в силу того, что традиционные вероисповедания, так называемые мировые религии, находят все больше точек соприкосновения на фоне их противостояния нетрадиционной религиозности. Необходимо отметить, что роль православия как субъекта межрелигиозного диалога в настоящее время во многом детерминирована его положением в конкретных государствах. В России, Болгарии, Сербии, Румынии, Греции и ряде других стран большинство верующих людей относят себя именно к православию. Сказанное справедливо и для Республики Беларусь. Более того, в преамбуле Закона Республики Беларусь «О свободе совести и религиозных организациях» подчеркивается, что он исходит из «признания определяющей роли Православной Церкви в историческом становлении и развитии духовных, культурных и государственных традиций белорусского народа» [3, с. 2]. Конечно, сказанное не означает, что в данной ситуации Православная Церковь должна вести межрелигиозный диалог с другими конфессиями с позиции приоритета, поскольку в юридическом отношении в государстве все религии равны, но она должна постоянно чувствовать ту огромную ответственность за сохранение указанных в данном законе духовных, культурных и государственных традиций нашего белорусского народа.

Безусловно, межрелигиозный диалог может вестись как внутри отдельного государства, так и между представителями конфессий, действующих на территории разных государств. Более того, такой диалог может иметь сверхрелигиозное, светское значение, то есть плодотворно влиять и на позитивное развитие межгосударственных отношений. Важность данного общественного феномена отмечается, например, в «Основах социальной концепции Русской Православной Церкви». «В истории Православия, - говорится в этом документе, - есть примеры положительного воздействия Церкви на развитие региональных межгосударственных связей» [4, с. 84]. Отметим, что особую роль в развитии межгосударственного сотрудничества Православная Церковь играет благодаря своей разносторонней миротворческой деятельности. Методологической основой данной деятельности являются слова Священного Писания, принадлежащие первоверховному апостолу Павлу, высказанная им мысль о социальной сущности христианства в послании к галатам: «Нет уже иудея, ни язычника; нет раба, ни свободного; нет мужского пола, ни женского: ибо все вы одно во Христе Иисусе» (Гал. 3:28). Как мы видим, апостол говорит о единстве во Христе не только социально отличающихся между собой групп: свободных и рабов, мужчин и женщин, но также и о различающихся по вероисповеданию (иудеев и язычников, что на тот момент времени было наиболее актуальным). Онтологической основой указанного единства является божественная любовь ко всему человечеству, ради спасения которого он дал распять Себя. В Евангелии от Иоанна приведены следующие слова Иисуса Христа: «Заповедь новую даю вам, да любите друг друга; как Я возлюбил вас, так и вы да любите друг друга. По тому узнают все, что вы Мои ученики, если будете иметь любовь между собою» (Ин. 13:34-35). Следовательно, православные люди должны действовать всегда, и в современном мире в том числе, исходя из этого постулата. На наш взгляд, в наибольшей степени любовь проявляется именно в миротворческой деятельности.

Конечно, в некоторых ситуациях, при определенных исторических обстоятельствах, православная церковь призывала народ к участию в военных действиях. Так произошло, например, в начале Великой Отечественной войны. Русская Православная Церковь в лице своего руководителя Патриаршего местоблюстителя Сергия (Страгородского), 
митрополита Московского и Коломенского, призвала всех православных людей к вооруженному сопротивлению немецким агрессорам. Уже 22 июня 1941 года он собственно отпечатал на пишущей машинке «Послание пастырям и пасомым Христовой Православной Церкви». В этом послании содержался призыв ко всем православным людям встать на защиту Родины. Оно было разослано по всем приходам. Причем, сама Церковь претерпела страшные гонения от богоборческой советской власти, но несмотря на это, она сумела преодолеть все обиды и призвала народ защищать свою Родину. Более того, многие православные священники не ограничились проповедями, но и участвовали в боевых действиях в армии и в партизанских отрядах.

Необходимо пояснить, что никакого противоречия с миротворческой деятельностью православной церкви в данном случае не существует. Ведь наряду с призывами к вооруженному сопротивлению оккупантам, православные священники одновременно вели и духовную брань: они молились за мир. Причем за мир не только для России (или СССР), но также и за мир во всем мире, имея многовековую молитвенную традицию, например, в виде прошения великой ектении: «О мире всего мира, благостоянии Святых Божиих Церквей и соединении всех Господу помолимся». Во что писал об этом феномене старец архимандрит Софроний (Сахаров) уже после войны своим близким родственникам в Россию: «В те кошмарные годы я подолгу молился, особенно по ночам. Часами рыдал в моих молитвах, «о мире всего мира», больше же всего за Россию, за русский народ, которому грозила наибольшая опасность едва ли не полного уничтожения» [2, с. 196-197].

Важно понимать, что любовь к людям не означает отсутствия ненависти к их греховным мыслям и практическим действиям. Вот почему для борьбы с различными грехами современного человечества Православная Церковь участвует в диалоге с представителями других религиозных конфессий, в том числе и нехристианских. Причем готова не только к чисто теоретическому диалогу, но и к совместным практическим действиям. Более того, церковь призывает своих верующих вместе со всеми нравственно здоровыми силами общества к совместной борьбе с такими широко распространенными в настоящее время грехами, которые, например, ведут к разрушению семьи и подрывают основы общества [4, с. 54]. Кроме того, в современном мире большое распространение также получили алкоголизм и наркомания. В связи с этим православная церковь участвует в межрелигиозном диалоге с целью выработки совместных социальных программ оказания помощи зависимым от этих грехов людям. Диалог также возможен в области культуры, может быть направлен на деятельность, способствующую сохранению и восстановлению национальных культурных ценностей, подвергающихся процессу разрушения.

Важно понимать, что отмеченные нами виды межрелигиозного сотрудничества не носят чисто религиозного характера. Дело в том, что с православной точки зрения духовным является только то, что характеризует взаимосвязь человека с Богом. Согласно христианской антропологии, каждому человеку с рождения дается частица Божьего Духа, которая является главной составляющей человеческой сущности, как элемент образа и подобия самого Творца. Дается с той целью, чтобы человек мог в правильном направлении осуществлять всю свою земную жизнь. Таким образом, исходя из данного понимания можно прийти к выводу о том, что приведенные примеры не являются образцом именно межрелигиозного духовного диалога. В данном случае это нравственный и культурологический диалог между представителями различных вероисповеданий, государств и социальных сообществ. С другой стороны, сама человеческая нравственность не является и чисто социальным феноменом, она не самодостаточна. В ее онтологической основе лежит нечто более высокое. Как отмечал святитель Игнатий Брянчанинов: «Нравственная сила человека - дух его» [5, c. 275]. Более того, в процессе межрелигиозного диалога задействованными оказываются не только нравственные чувства, но также и мышление. «Не может мысль быть без духа, продолжает свою мысль святитель, - существование одной непременно сопутствуется существованием другого. В существовании того и другого является существование ума» [5, с. 275]. Следовательно, диалог, касающийся нравственных и других социальных проблем, в какой-то степени всегда будет иметь опосредованный духовный характер. По крайней 
мере, он может основываться на духовных началах, даже в том случае, если это и не провозглашается в явном виде.

Конечно, в процессе межрелигиозного диалога происходит не только поиск решения конкретных практических задач, но также и поиск истины. Однако данный процесс не касается высшей христианской Истины. Дело в том, что Православная Церковь полагает, что Истина уже найдена. Причем, не в результате особых логических рассуждений или других гносеологических приемов. По мнению русского философа П. А. Флоренского (1882-1937), она открывается людям мистическим способом. Как именно это происходит «не знаем, и знать не можем, - писал отец Павел в работе «Столп и утверждение Истины», - знаем только, что сквозь зияющие трещины человеческого рассудка видна бывает лазурь вечности. Это непостижимо, но это - так» [6, с. 489]. Данная Истина есть не что иное, как сам Бог. Таким образом, она имеет не гносеологический, а онтологический характер. Более того, по существу, не человек познает эту Истину, а она сама открывается людям. «Бог Авраама, Исаака, Иакова, а не бог философов и ученых приходит к нам, приходит к одру ночному, берет нас за руку и ведет так, как мы не могли бы и подумать» [6, с. 489]. Естественно, православная церковь, исходя из того, что в ней присутствует высшая Истина в наиболее полном проявлении, не нуждается в диалоге с другими религиями относительно нее.

Сказанное, однако, не означает, что церковь выступает против именно межрелигиозного диалога, касающегося чисто практических вопросов. Дело в том, что диалог - это не только поиск истины, но и возможность перенимать все лучшее в культуре и других социальных феноменах. Отметим, что существуют два варианта понимания самого слова «культура». Во-первых, перевод латинского слова «cultura» означает «возделывание», a, во-вторых, - оно может трактоваться как однокоренное слову «культ». Для межрелигиозного диалога наиболее важно именно второе толкование. Исходное значение указывает на онтологические религиозные корни культуры. С другой стороны, существует и обратная зависимость. Как отмечается в «Основах социальной концепции Русской Православной Церкви»: «Церковь восприняла многое из созданного человечеством в области искусства и культуры, переплавляя плоды творчества в горниле религиозного опыта, стремясь очистить их от душепагубных элементов, а затем преподать людям. Она освящает различные стороны культуры и многое дает для ее развития» [16, с. 76]. Таким образом, сотрудничество в области культуры означает в первую очередь взаимодействие в области духовной, в области музыки, изобразительного и декоративно-прикладного искусства, кинематографа. Возможно проведение совместных с представителями других конфессий и светскими организациями фестивалей, концертов, арт-проектов и т.д.

Очень важно то, что исторически сложившаяся в России и Беларуси практика межрелигиозного диалога, осуществляемая православной церковью, предполагала наличие уважения не только к традициям и образу жизни различных религиозных общин, но также и к их вероучению. Однако такое уважительное отношение не означало стремления к объединению или смешению православия с другими вероисповеданиями. Православные люди всегда считали, что именно от чистоты их веры зависит не только вечное, внеземное бытие, но и правильная земная личная и общественная жизнь, нравственные нормы, относящиеся к хранению внутренней духовного благоговения перед Богом, осуждение любого греха, даже если этот грех не приносит никому, кроме себя самого, ощутимого вреда.

Кроме того, с православной точки зрения, необходимо честно отражать, в том числе и в межрелигиозных заявлениях, всю полноту согласия или, напротив, несогласия по вероучительным вопросам: духу православия чужд вероучительный экуменизм. Конечно, сторонники объединения церквей утверждают, что все религии - это путь к Богу, к истине. Для оправдания своей точки зрения они ссылаются на следующие слова апостола Павла, сказанные им в послании к ефесянам: «Один Господь, одна вера, одно крещение, один Бог и Отец всех, который над всеми» (Еф. 4: 5-6). Но здесь апостол утверждает, что существует только лишь одна вера правильная, а остальные являются в той или иной степени заблуждением. Православные христиане уверены в том, что существует только лишь единая Истина, открытая всем людям самим Богом, через Его откровение и доступная постижению. 
Более того, в процессе межрелигиозного и межкультурного диалога они обязаны оставаться верными ей. Именно таким способом, а не так называемым толерантным относительно собственных религиозных убеждений, можно принести благо не только себе, но и другим участникам диалога. Такая твердость в вере может вдохновить и других стремлением к познанию подлинной Истины.

Необходимо отметить, что сама по себе тенденция к объединению религий носит достаточно спорный и скорее негативный характер. Как подчеркивает известный российский писатель-публицист Т. М. Горичева в своей работе «Об обновленчестве, экуменизме и «политграмотности верующих», необходимо задать себе вопрос о том, чем именно будет полезно экуменическое единство православных с католиками и протестантами, не говоря уже о представителях нехристианских религий. Только на первый взгляд может показаться, что всякая интеграция несет безусловный прогресс в развитии. На самом же деле, в результате данного процесса можно потерять ту абсолютную Истину, которую имеем, и не получить ничего взамен [1, с. 7-8]. Толерантность в чисто религиозных вопросах, по существу, может обернуться предательством своей веры. Более того, примечательно, что помимо социально-политического и культурного смысла, само слово «толерантность» означает еще и потерю организмом способности вырабатывать антитела на соответствующее антигенное воздействие. Таким образом, в результате подобной мутации человек лишается способности адекватно реагировать на внешние воздействия и может умереть. Применительно к религиозному контексту, это может означать смерть духовную.

В заключение исследования необходимо отметить, что в настоящее время голос православной церкви на мировой арене звучит достаточно ясно, является символом сохранения традиционных христианских ценностей, поддержки институтов семьи и государства.

Литература

1. Горичева, Т. Об обновленчестве, экуменизме и «политграмотности» верующих: взгляд русского человека, живущего на Западе / Т. Горичева. - Санкт-Петербург: Сатисъ, 1997. $-48 \mathrm{c.}$

2. За Веру и Отечество. - Москва : Даръ, 2006. - 384 с.

3. О свободе совести и религиозных организациях : Закон Республики Беларусь. - Минск, 2002. -24 c.

4. Основы социальной концепции Русской Православной Церкви. - Москва, 2000. - 88 с.

5. Святитель Игнатий Брянчанинов. Избранные творения / Игнатий Брянчанинов, святитель. - Москва : Духовное преображение, 2014. - 816 с.

6. Флоренский, П. А. Столп и утверждение истины / П. А. Флоренский. - Том 1 (I). Москва : Правда, 1990. - 490 с.

В статье исследуется роль православия как субъекта межрелигиозного и межкультурного диалога и анализируется деятельность Православной Церкви на мировой арене. Особо отмечается миротворческая деятельность и сотрудничество с различными организациями в рамках социальных программ по нравственному воспитанию. Для борьбы с грехами современного человечества Православная Церковь участвует в диалоге с представителями других религиозных конфессий, в том числе и нехристианских. Духу православия чужд вероучительный экуменизм, однако межрелигиозный диалог - это не только поиск истины, но и возможность перенимать лучшие достижения в культуре и других социальных феноменах.

The article explores the role of Orthodoxy as a subject of interreligious and intercultural dialogue and analyzes the activities of the Orthodox Church in the world arena. Peacekeeping activities and cooperation with various organizations within the framework of social programs for moral education are especially noted. To struggle with the sins of modern mankind, the Orthodox Church participates in a dialogue with representatives of other religious confessions, including nonChristian ones. The spirit of Orthodoxy is alien to doctrinal ecumenism, but interreligious dialogue is not only a search for truth, but also an opportunity to adopt the best achievements in culture and other social phenomena. 